\title{
Correction to: Cognitive Vulnerability in the Context of Panic: Assessment of Panic-Related Associations and Interpretations in Individuals with Varying Levels of Anxiety Sensitivity
}

\author{
Lisa Zahler $^{1} \cdot$ Katharina Sommer $^{1} \cdot$ Andrea Reinecke $^{2} \cdot$ Frank H. Wilhelm $^{3} \cdot$ Jürgen Margraf $^{1} \cdot$ Marcella L. Woud $^{1}$
}

Published online: 23 October 2021

(c) The Author(s) 2021

\section{Correction to: Cognitive Therapy and Research(2020) 44:858-873 https://doi.org/10.1007/s10608-020-10103-6}

The article "Cognitive Vulnerability in the Context of Panic: Assessment of Panic-Related Associations and Interpretations in Individuals with Varying Levels of Anxiety Sensitivity", written by Lisa Zahler, Katharina Sommer, Andrea Reinecke, Frank H. Wilhelm, Jürgen Margraf, Marcella L. Woud, was originally published electronically on the publisher's internet portal on 25 April 2020 without open access. With the author(s)' decision to opt for Open Choice the copyright of the article changed on 30 September 2021 to (C) The Author(s) 2020 and the article is forthwith distributed under a Creative Commons Attribution 4.0 International License, which permits use, sharing, adaptation, distribution and reproduction in any medium or format, as long as

The original article can be found online at https://doi.org/10.1007/ s10608-020-10103-6.

Marcella L. Woud

Marcella.Woud@rub.de

1 Mental Health Research and Treatment Center, Department of Psychology, Ruhr-Universität Bochum, Massenbergstraße 9-13, 44787 Bochum, Germany

2 Department of Psychiatry, University of Oxford, Warneford Hospital, Warneford Ln, Oxford OX3 7JX, UK

3 Division of Clinical Psychology, Psychotherapy, and Health Psychology, Department of Psychology, University of Salzburg, Hellbrunnerstrasse 34, 5020 Salzburg, Austria you give appropriate credit to the original author(s) and the source, provide a link to the Creative Commons licence, and indicate if changes were made. The images or other third party material in this article are included in the article's Creative Commons licence, unless indicated otherwise in a credit line to the material. If material is not included in the article's Creative Commons licence and your intended use is not permitted by statutory regulation or exceeds the permitted use, you will need to obtain permission directly from the copyright holder. To view a copy of this licence, visit http:// creativecommons.org/licenses/by/4.0. The original article has been corrected.

Open Access This article is licensed under a Creative Commons Attribution 4.0 International License, which permits use, sharing, adaptation, distribution and reproduction in any medium or format, as long as you give appropriate credit to the original author(s) and the source, provide a link to the Creative Commons licence, and indicate if changes were made. The images or other third party material in this article are included in the article's Creative Commons licence, unless indicated otherwise in a credit line to the material. If material is not included in the article's Creative Commons licence and your intended use is not permitted by statutory regulation or exceeds the permitted use, you will need to obtain permission directly from the copyright holder. To view a copy of this licence, visit http://creativecommons.org/licenses/by/4.0/.

Publisher's Note Springer Nature remains neutral with regard to jurisdictional claims in published maps and institutional affiliations. 